\title{
Analisis konvergensi simbolik dalam media sosial youth group terkait kasus COVID-19 di Indonesia
}

\author{
Sri Seti Indriani ${ }^{1}$, Ditha Prasanti ${ }^{2}$ \\ ${ }^{1,2}$ Universitas Padjadjaran, Bandung, Indonesia
}

\begin{abstract}
ABSTRAK
Pada awal tahun 2020, Organisasi Kesehatan Dunia mengumumkan COVID-19 sebagai pandemi yang mengejutkan dunia. Virus yang menular dan berbahaya ini melumpuhkan sebagian besar negara di dunia. Paparan media tentang virus menyebabkan berbagai spekulasi dan asumsi tentang virus. Diskusi tentang virus menjadi terhangat yang diperbincangkan oleh berbagai kalangan dalam segala bentuk media massa, termasuk sebuah komunitas dalam media sosial. Sekelompok remaja dalam group WhatsApp bernama Monster Rabbits' yang juga menjadikan kasus ini sebagai salah satu topik yang selalu diperbincangkan. Tujuan penelitian adalah mengungkapkan tema diskusi mereka, mengungkap rantai tema yang terbentuk dalam kelompok terkait dengan kasus COVID-19, dan untuk mengenali budaya obrolan mereka dalam kelompok. Teori konvergensi simbolik menjadi teori yang relevan untuk mendukung penelitian ini. Penelitian dilakukan dengan pendekatan kualitatif menggunakan metode etnografi virtual. Teknik pengumpulan data yang digunakan adalah wawancara offline-online, observasi, dan studi dokumentasi. Hasilnya menunjukkan bahwa tema yang terbentuk adalah tentang kesadaran mereka akan virus. Rantai yang terbentuk dalam percakapan dimulai dengan kasus COVID-19 di mana mereka mendapatkan sebagian besar informasi, perasaan mereka tentang hal itu, dan langkah-langkah untuk mencegah diri mereka sendiri dalam pengananan virus. Bagian terakhir dari diskusi adalah tema-tema yang mengungkap rantai fantasi yang memperdebatkan bagaimana virus dapat muncul di tempat pertama dan menyebar ke seluruh dunia. Budaya obrolan yang ditunjukkan dalam kelompok terdiri dari empat kategori, yaitu; penggunaan bahasa sehari-hari, penggunaan stiker yang difasilitasi oleh aplikasi, penggunaan screen shoot gambar dari situs web lain, dan penggunaan bahasa campuran antara Indonesia dan Inggris.
\end{abstract}

Kata-kata Kunci: Konvergensi simbolik; media sosial; COVID-19; budaya berbicara; tema fantasi

\section{Symbolic convergence analysis in youth group's social media related to the case of COVID-19 in Indonesia}

\begin{abstract}
In early 2020, the World Health Organization declared COVID-19 as a pandemic, which shocked the world. This contagious and dangerous virus paralyzes most countries in the world. Media exposure to the virus has led to various speculations and assumptions about the virus. Discussions about the virus are the most animated discussion in various groups in all forms of mass media, including a community on social media. A group of teenagers in the WhatsApp group called Monster Rabbits'also makes this case one of the continuously discussed topics. The research objectives are to reveal the themes of their discussion, explore the chain of themes formed in groups related to the COVID-19 case, and identify their chat culture. The theory of symbolic convergence is a relevant theory to support this research, which was conducted with a qualitative approach by implementing virtual ethnographic methods. The data collection techniques used were offline-online interviews, observation, and documentation study. The results showed that the formed theme was about their awareness of the virus. The chain that forms in the conversation begins with the COVID-19 case where they got most of the information, how they feel about it, and steps to prevent themselves from getting the virus. The final part of the discussion is the themes that unravel the fantasy chain, debating how the virus could have emerged in the first place and spread around the world. The chat culture shown in the group consists of four categories: use of everyday language, use of stickers facilitated by the application, use of screenshots of images from other websites, and use of mixed language between Indonesian and English.
\end{abstract}

Keywords: Symbolic convergence; social media; COVID-19; speaking culture; fantasy theme

Korespondensi: Dr. Sri Seti Indriani, M,Si. Universitas Padjadjaran. J1 Raya Jatinangor - Bandung KM.21 Jatinangor.Email: seti@unpad.ac.id 


\section{PENDAHULUAN}

Coronavirus atau COVID-19, siapa yang tak mengenal kata tersebut? Kata yang sangat mengejutkan bagi seluruh individu di dunia saat ini. Mayoritas individu tidak menyangka bahwa virus ini bisa menular dan juga mematikan. Data yang diperoleh hingga 22 April 2020, ada lebih dari 2,5 juta kasus yang dikonfirmasi dari coronavirus di 185 negara ketika penyakit ini terus menyebar (Team, 2020). Berbagai negara pun melakukan sistem lockdown, pertama kalinya dunia pun mengalami fenomena panic buying tidak dapat dihindari. Pada 11 Maret, Organisasi Kesehatan Dunia (WHO) menyatakan COVID-19 sebagai pandemi di dunia. WHO mengungkapkan ada lebih dari 118.000 kasus penyakit coronavirus di lebih dari 110 negara dan wilayah di seluruh dunia dan risiko berkelanjutan yang menyebabkan penyebaran global lebih lanjut (Ducharme, 2020).

Pada awal wabah virus muncul, sebagian besar masyarakat menganggap remeh virus ini. Begitupun halnya mayoritas individu di seluruh dunia berpikir bahwa orang-orang percaya bahwa virus itu hanya penyakit yang akan menyebar di Wuhan, Cina, dan juga berakhir di sana, sebagai tempat pertama kali ditemukan. Pada mulanya, Indonesia juga menjadi salah satu negara yang tidak menaruh perhatian besar pada virus tersebut. Sebaliknya, ketika beberapa negara mulai menerapkan kebijakan lockdown, pemerintah Indonesia menganggarkan $\mathrm{Rp}$ 72 miliar untuk mendanai pengguna media sosial dalam paket insentif pariwisata untuk melawan dampak negatif dari virus Corona atau COVID-19 (Diantina, 2020).

Setelah adanya pasien pertama terpapar COVID-19 di Jakarta, maka hal tersebut menjadi alarm bagi Indonesia. Kemudian berbagai informasi hoaks pun mulai muncul dalam media sosial yang dikaitkan dengan COVID-19 sehingga membuat orang menjadi lebih khawatir. Salah satunya pun terjadi pada berbagai grup dalam media sosial, yang dibanjiri dengan diskusi dan berbagi informasi tentang COVID-19. Perdebatan pun terjadi dalam grup media sosial, mulai dari seputar bagaimana bahaya COVID-19, proses menularnya virus tersebut, dan upaya yang dapat dilakukan dalam mencegah diri dari virus tersebut. Percakapan yang panjang menyebabkan berbagai asumsi dan pendapat yang menciptakan tema fantasi yang juga berasal dari cerita konspirasi dari informasi yang menyesatkan. Hal inilah yang menarik perhatian penulis untuk mengangkat topik tersebut. Fokus penelitian peneliti dalam hal ini adalah obrolan yang terjadi dalam sebuah WhatsApp Group bernama Monster Rabbit, yaitu sebuah kelompok remaja yang aktif memperbincangkan semua hal tentang COVID-19.

Munculnya COVID-19 juga menarik perhatian berbagai peneliti dari disiplin ilmu yang beragam. Misalnya saja, Reuters Institute for Study of Journalism di Oxford University, sepertiga pengguna media sosial di seluruh Amerika Serikat, serta Argentina, Jerman, Korea Selatan, Spanyol dan Inggris, mengungkapkan tentang adanya informasi yang salah dan menyesatkan tentang coronavirus (Sucio, 2020). Informasi yang menyesatkan atau disebut juga hoaks tersebut mengakibatkan ketakutan yang luar biasa terhadap masyarakat tentang COVID-19, termasuk di Indonesia. UNICEF yang bekerja sama dengan pemerintah Indonesia melakukan polling untuk menguji pengetahuan kaum muda melalui U-report, alat keterlibatan pemuda digital dengan lebih dari 68 juta pengguna di seluruh dunia. Ada 63\% laki-laki dan $70 \%$ responden perempuan di Indonesia memahami gejala-gejalanya, tetapi kurang dari seperempatnya mengetahui bahwa COVID-19 dapat ditularkan melalui tetesan yang disebarkan melalui batuk dan bersin (Rheddy, 2020).

Kondisi pandemi COVID-19 juga menyebabkan terjadinya krisis kesehatan global besar-besaran. Dalam penelitiannya juga membahas bukti dari sejumlah pilihan topik penelitian yang relevan dengan pandemi, termasuk pekerjaan tentang menavigasi ancaman, pengaruh sosial dan budaya pada perilaku, pengambilan keputusan moral, kepemimpinan, dan stres dan pencegahannya. Di setiap bagian, kami mencatat sifat dan kualitas penelitian sebelumnya, termasuk ketidakpastian dan masalah yang belum diselesaikan. Mereka mengidentifikasi beberapa wawasan tentang respons efektif terhadap pandemi COVID-19 dan menyoroti kesenjangan penting yang harus diatasi oleh para peneliti untuk mengisi beberapa minggu dan bulan mendatang (Van Bavel et al., 2020)

Chan juga mengungkapkan hal yang 
serupa tentang pandemi COVID-19 yang mengancam kesehatan global (Chan, et all, 2020). Tingkat infeksi di luar China meningkat dengan cepat, dengan kasus yang dikonfirmasi dilaporkan lebih dari 160 negara pada 19 Maret 2020. Sebuah studi baru-baru ini dari Wuhan, Cina, melaporkan bahwa ada 1716 petugas layanan kesehatan terinfeksi COVID-19, mewakili 3,8\% dari kasus yang dikonfirmasi. Dengan demikian, penyampaian informasi yang cepat membahas masalah pengendalian infeksi kritis adalah sangat penting terkait dengan risiko tinggi penularan infeksi virus kepada petugas kesehatan. Tantangannya adalah bagaimana mentransfer pengetahuan tentang praktik terbaik saat ini kepada orangorang yang paling membutuhkannya, dengan kecepatan yang sama atau lebih baik daripada epidemi yang menyebar. Oleh karena itu, jalur penyebaran publikasi ilmiah tradisional, situs web statis, dan bahkan email diketahui lambat. Akses internet di seluruh dunia telah mapan, namun mendapatkan akses ke pengguna medis potensial sebagian besar bergantung pada kontak email dan alat komunikasi pribadi. Akses materi pendidikan terbuka gratis yang dirancang dengan baik harus menyaring informasi inti dalam format yang jelas dan dapat ditindaklanjuti, sementara dipasangkan dengan sosialisasi yang diberdayakan media sosial menggunakan jejaring sosial, di samping metode komunikasi tradisional. Oleh karena itu, pemanfaatan media sosial dengan cara ini telah menunjukkan harapan sebagai alternatif yang lebih cepat (Chan, et al., 2020).

Sementara itu, Kobayashi melakukan penelitian tentang COVID-19 dari perpektif ilmu kesehatan dalam mengungkapkan tingkat keparahan infeksi untuk penyakit tertentu, yang didefinisikan sebagai risiko kematian di antara beberapa kasus (Kobayashi, et.all, 2020). Namun, ada tiga kendala teknis yang harus diatasi untuk mengukur risiko ini dengan tepat. Pertama, pembagian jumlah kumulatif kematian berdasarkan kasus cenderung meremehkan risiko yang sebenarnya karena kematian yang akan terjadi belum diamati, sehingga penundaan waktu dari penyakit pada kematian harus ditangani. Kedua, data yang diamati dari kasus yang dilaporkan hanya mewakili sebagian dari semua orang yang terinfeksi dan mungkin ada sejumlah besar orang yang tidak menunjukkan gejala dan orang yang terinfeksi ringan yang tidak pernah didiagnosis. Ketiga, bias kepastian dan risiko kematian di antara semua yang terinfeksi akan lebih kecil bila diperkirakan menggunakan jendela deteksi virus yang lebih pendek dan tes laboratorium diagnostik yang kurang sensitif. Dalam epidemi COVID-19 yang sedang berlangsung, otoritas kesehatan harus mengatasi ketidakpastian risiko kematian akibat COVID-19, dan individu yang berisiko tinggi harus diidentifikasi menggunakan pendekatan yang dapat mengatasi tiga masalah tersebut. Meskipun COVID-19 melibatkan infeksi ringan di antara sebagian besar populasi umum, risiko kematian pada orang dewasa muda lebih tinggi daripada influenza musiman, dan orang tua dengan komorbiditas yang mendasarinya sehingga membutuhkan perawatan tambahan (Kobayashi et al., 2020).

Dalam dispilin ilmu yang lain, ada hasil penelitian yaitu mengungkapkan hambatan utama untuk mempertahankan perawatan biasa dengan telemedis. Menurutnya, hanya 20\% negara bagian yang mensyaratkan kebijakan pembayaran antara layanan telemedis dan tatap muka. Pusat Layanan Medicare dan Medicaid, serta beberapa layanan komersial lokal telah mengubah kebijakan pembayaran dalam upaya menanggapi COVID-19. Mereka berharap orang lain akan mengikuti. Bencana dan pandemi menimbulkan tantangan unik dalam pemberian layanan kesehatan. Meskipun telehealth tidak akan menyelesaikan semuanya, hal tersebut sangat cocok dalam skenario di mana infrastruktur tetap utuh. Struktur pembayaran dan pengaturan, perizinan negara, dan implementasi program, semuanya membutuhkan waktu untuk dikerjakan, tetapi sistem kesehatan yang telah berinvestasi dalam telemedicine diposisikan dengan baik untuk memastikan bahwa pasien dengan COVID-19 akan menerima perawatan yang mereka butuhkan. Dalam hal ini, menurut Hollander \& Carr (2020), kebijakan tersebut menjadi solusi yang hampir sempurna (Hollander \& Carr, 2020).

Sementara itu, penulis juga menemukan hasil penelitian yang berfokus pada paparan media tentang COVID-19. Peneliti lain juga melihat virus ini pada fokus paparan media tentang pandemik tersebut. Mereka menyebutkan bahwa COVID-19 telah menyebabkan wabah penyakit pernapasan yang sangat serius, berasal dari Cina, menjadi 
pandemi global, dengan konsekuensi luas yang belum pernah terjadi sebelumnya di era modern. Ketika para pejabat kesehatan publik berupaya untuk menahan virus dan mengurangi dampak buruknya terhadap kesehatan populasi dunia, muncul ancaman terkait yaitu tentang paparan media global terhadap krisis.

Garfin, Silver, \& Holman juga meninjau penelitian yang menunjukkan bahwa paparan media yang berulang-ulang terhadap krisis komunitas dapat meningkatkan kecemasan, respons stres yang meningkat sehingga mengarah pada efek hilir pada kesehatan, dan salah menempatkan perilaku yang melindungi kesehatan, serta mencari pertolongan yang dapat membebani fasilitas perawatan kesehatan dan sumber daya pajak yang tersedia (Garfin, Silver, \& Holman, 2020). Menurutnya, mereka dapat belajar dari krisis kesehatan masyarakat sebelumnya (yaitu, wabah Ebola dan H1N1) dan trauma kolektif lainnya (misalnya, serangan teroris) di mana liputan media tentang peristiwa memiliki konsekuensi yang tidak disengaja bagi mereka yang berisiko relatif rendah, yang mengarah pada publik yang berpotensi memiliki dampak kesehatan tinggi. Mereka juga menyimpulkan dengan rekomendasi untuk individu, peneliti, dan pejabat kesehatan masyarakat sehubungan dengan menerima dan menyediakan komunikasi yang efektif selama krisis kesehatan masyarakat (Garfin, Silver, \& Holman, 2020).

Demikianlah berbagai penelitian yang mengungkapkan perspektif berbeda tentang COVID-19. Temuan tersebut menguatkan penulis dalam mengangkat topik penelitian yang serupa dalam fokus kajian tentang penyebaran informasi COVID-19 di Indonesia, sehingga dalam diskusi yang paling menarik pun terjadi pada sebuah WhatsApp Group bernama "Monster Rabbit". Sekelompok remaja yang ikut aktif melakukan perbincangan dalam WhatsApp Group tersebut tentang informasi COVID-19, mulai dari proses penyebarannya di tempat pertama dan berbagai informasi penting lainnya tentang dampak COVID-19 tersebut.

Selain itu, fokus penelitian yang diangkat penulis juga dapat melengkapi hasil temuan tentang pandemik COVID-19 yang menyebabkan arus penyebaran informasi membanjiri berbagai kelompok dalam platform media sosial.

Berdasarkan latar belakang di atas, maka penulis semakin tertarik dalam mengungkapkan lebih lanjut tentang penyebaran informasi COVID-19 dalam percakapan yang terjadi pada WhatsApp Group bernama "Monster Rabbit". Mereka mengakui tema fantasi dalam kelompok remaja tentang tema fantasi yang ditautkan dengan COVID-19. Kelompok remaja tersebut adalah sekelompok remaja berusia 12 hingga 15 tahun yang masih duduk di bangku SMP. Grup ini disebut "Monster Rabbit". Penelitian ini menggunakan konvergensi Teori Simbolik yang merupakan teori yang relevan untuk membahas tema fantasi dalam kelompok kecil. Proses percakapan dalam grup ini diproduksi di media sosial online WhatsApp, yang kemudian menggunakan metode etnografi virtual. Apa yang membuatnya menarik tentang kelompok ini adalah kepedulian mereka dalam kasus COVID-19 ini dan bagaimana mereka menciptakan tema fantasi yang luas yang dikaitkan dengan virus tersebut. Penelitian inipun berfokus pada 'Bagaimana tema fantasi diciptakan melalui kelompok yang terhubung dengan COVID-19 "dengan pertanyaan penelitian tentang topik percakapan apa yang didiskusikan anggota? Bagaimana tema rantai terbentuk dalam percakapan sebagai tanggapan terhadap kasus COVID-19? Selain itu, bagaimana budaya bicara terbentuk dalam kelompok dalam menanggapi situasi COVID-19?

Ada banyak penelitian tentang kelompok kecil atau kelompok organisasi yang menggunakan Symbolic Convergence Theory (SCT) tentang tema yang berkembang dalam kelompok, tetapi tidak begitu banyak penelitian yang berfokus pada kelompok media sosial kecil terutama kelompok remaja. Sebuah riset kelompok online yang sangat mirip dan relevan adalah tentang kelompok remaja LINE 'Bedebah Cinta' yang menunjukkan bahwa ada jenis tema fantasi yang unik dan pembentukan rantai fantasi juga muncul dalam percakapan yang sedang berlangsung. Tema fantasi adalah mayoritas tentang cinta, jenis kelamin, wanita, dan persahabatan yang kemudian mengarah pada visi retoris (Prasanti \& Indriani, 2018).

Penelitian lain menggunakan Diskusi Kelompok Terfokus tentang komunitas virtual, Kompasiana dan Forum Indonesia Sejahtera (FIS). Konvergensi simbolik dalam Kompasiana dan FIS meningkat secara signifikan dan terjadi dari struktur dasar, struktur pesan, struktur 
dinamis, struktur evaluatif, dan struktur komunikasi (Heryanto, 2015). Seperti yang terlihat dari penelitian di atas, teori konvergensi simbolik juga menyediakan temuan terkait dengan tema yang muncul dalam kelompok media online yang dapat dilihat melalui bagaimana percakapan itu mungkin terstruktur.

Ernest Borman menciptakan teori konvergensi simbolik, yang merupakan teori komunikasi umum. Ini menjelaskan proses di mana tema konten yang muncul dalam fungsi retorika secara dramatis untuk menghubungkan audiens dengan pesan (Littlejohn, Foss, \& Vaughan, 2012).

Selain itu, Borman juga menggambarkan teori ini sebagai proses interaktif di mana manusia bertemu dengan menceritakan fantasi individu, mimpi, harapan, atau ketakutan dalam sistem simbol bersama dan menawarkan kerangka kerja analitis yang kaku. Kerangka kerja ini menangkap perkembangan dinamis penciptaan makna dalam kelompok (Gyimothy, 2013).

Pesan-pesanyangmendramatisirmelibatkan anggota yang memperkenalkan contoh-contoh singkat tentang humor, permainan kata, dan kiasan, atau analogi, dongeng, atau narasi yang lebih terperinci (Zanin, Hoelscher, \& Kramer, 2016). Fantasi ini tidak memfasilitasi cerita fiktif atau keinginan erotis. Fantasi adalah cerita atau humor yang mengandung emosi.

Fantasi merupakan peristiwa dari anggota grup di masa lalu atau peristiwa di masa depan. Fantasi tidak mencakup komunikasi yang berfokus pada apa yang terjadi dalam kelompok. Ada empat istilah utama dalam analisis fantasi ini; tema fantasi, rantai fantasi, tipe fantasi, dan visi retoris.

Teori konvergensi simbolik menciptakan proses komunikasi yang meliputi pesan dramatisasi, rantai fantasi, tema fantasi, tipe fantasi, dan visi retoris. Ketika anggota mulai memperkenalkan contoh singkat tentang humor, permainan kata, dan kiasan, atau analogi, dongeng, atau narasi yang lebih rumit, pengantar ini kadang-kadang menghasilkan pesan serupa yang dikenal sebagai perubahan fantasi. Rantai fantasi dapat berlangsung berulang kali, yang kemudian mengarah ke tema fantasi. Tema-tema ini menciptakan pemahaman bersama tentang tindakan masa lalu dan masa depan. Beberapa tema fantasi dapat menjadi referensi untuk masalah serupa, dan ini menghasilkan jenis fantasi. Ketika suatu kelompok mengembangkan beberapa jenis fantasi, visi retoris kelompok muncul.

Visi retoris menghasilkan beberapa skrip dan memberikan anggota dalam kelompok pandangan yang lebih komprehensif. Ada lima elemen utama dalam visi retoris, pertama, kepribadian dramatis yang merupakan aktor atau pemain dalam sebuah cerita. Yang kedua adalah alur cerita tentang apa yang dibicarakan kelompok, atau situasi apa yang terjadi. Ketiga, adegan yang menguraikan detail deskriptif. Keempat, agen sanksi yang merupakan seseorang yang memiliki wewenang, seperti rasa moral yang disepakati, dan kelima analog master yang merupakan nilai-nilai inti dan struktur budaya (Zanin, Hoelscher, \& Kramer, 2016). Suryadi menyepakati empat dari lima elemen itu. Empat elemen penting dalam teori ini adalah karakter yang terlibat, alur cerita (alur cerita), latar dan agen yang menentukan kebenaran cerita (agen sanksi) (Suryadi, 2014).

Sementara itu, penelitian yang dilakukan penulis ini berfokus pada kelompok media sosial remaja online yang menyebut diri mereka sebagai sekelompok remaja yang ikut aktif melakukan perbincangan dalam WhatsApp Group tersebut tentang informasi COVID-19, mulai dari proses penyebarannya di tempat pertama dan berbagai informasi penting lainnya tentang dampak COVID-19 tersebut.

Para peneliti berpendapat bahwa jaringan relasional yang merupakan kelompok sosial medial menciptakan rasa memiliki dan bahwa jaringan online dapat melacak kontur divisi sosial yang ada saat mereka melampaui atau mengubahnya (Merchant, 2012). Grup media sosial tersebut pun dapat berperan penting dalam masyarakat, dari aspek penyebaran informasi. Disinilah kemudian akan terlihat pentingnya membedekan penyaringan informasi yang hoaks atau informasi yang benar.

Grup media sosial memiliki fungsi untuk menyampaikan informasi juga berfungsi sebagai media untuk diskusi dan pendidikan, sebagai media hiburan, dan sebagai media untuk mengerahkan pengaruh. Salah satu aplikasi media sosial yang paling disukai yang digunakan di Indonesia adalah WhatsApp. Aplikasi WhatsApp adalah salah satu platform yang paling banyak digunakan di Indonesia. Menurut Digital Report, data 2019 dari We Are Social, dan Hootsuite, 83 persen pengguna 
internet di Indonesia adalah pengguna WhatsApp (Wardani, 2020).

Beberapa penelitian mengakui banyak penggunaan aplikasi WhatsApp. Itu dianggap aman dan adapabe. Ada hubungan sosial, pendidikan, kesejahteraan, pekerjaan dan hiburan mengenai penggunaan aplikasi ini. Pesan dikirim lebih cepat dan juga memiliki fungsi organisasi. Terkait dengan pendidikan, ia juga dapat mengatur berbagai ruang kelas virtual online berbasis komunitas akademik (Jumiatmoko, 2016); Rahmansari, 2018); Trisnani, 2017). Lalu kaitannya dengan penelitian ini, penulis mengungkapkan percakapan remaja yang menamakan dirinya "Monster Rabbit". Teori konvergensi simbolik membantu penelitian ini untuk mengungkap tema yang terkait dengan COVID-19 yang menghubungkan anggota grup Whatsapp 'Monster Rabbit', yang kemudian mereka berfantasi konten yang mengidentifikasi anggota sebagai grup.

Penelitian tentang COVID-19, dalam beberapa bulan ini menjadi fokus kajian yang menjadi pusat perhatian para peneliti dari berbagai disiplin ilmu. Bagaimana tidak, wabah virus yang mengejutkan dunia mendorong banyak penelitian untuk melakukan penelitian tentang pandemi ini.

Begitupun Kumar yang telah melakukan tinjauan terhadap virus tersebut. COVID-19 menyebabkan infeksi pernafasan, termasuk pneumonia, pilek, bersin dan batuk. Virus menyebar dari manusia ke manusia melalui tetesan udara. Kemudian memasuki sel manusia melalui membran reseptor exopeptidase ACE-2 (Kumar, 2020). Oleh karena itu, alasan mengapa hal itu terjadi dan mengapa hal tersebut dapat muncul sehingga memicu masyarakat pada banyak tingkat diskusi termasuk kelompok WhatsApp"Rabbit Monster".

\section{METODE PENELITIAN}

Dalam penelitian ini, penulis menggunakan pendekatan kualitatif dengan metode etnografi virtual. Paradigma penelitian ini adalah interpretative, yaitu penelitian yang bersifat subjektif, mengasumsikan bahwa pengetahuan tidak memiliki sifat objektif, dan tidak memiliki keyakinan yang konstan.

Sebagaimana diungkapkan oleh ahli, Ada empat fitur spesifik dari penelitian kualitatif. Pertama adalah memahami makna peserta penelitian, selidiki. Kedua adalah untuk menyelidiki pengaruh konteks spesifik di mana individu dan kegiatan yang diteliti berada. Yang ketiga adalah untuk menjelaskan proses dimana makna dan konteks ini mengarah ke fitur atau hasil tertentu. Yang keempat adalah menggabungkan subjektivitas peneliti secara eksplisit (Maxwell \& Reybold, 2015).

Hine menggambarkan etnografi virtual dengan beberapa prinsip, pertama, pertanyaan tentang asumsi tentang internet yang diterima secara umum. Kedua, ia membedakan kehidupan nyata dan fenomena yang muncul dari interaksi tatap muka (Hine, 2001). Bidang internet adalah hubungan yang sangat kompleks yang terjadi berdasarkan konteks yang digunakan termasuk penggunaan teknologi (Prasanti \& Indriani, 2019).

Dalam hal ini, penulis melakukan penelitian offline, yaitu bertemu langsung dengan informan untuk melakukan wawancara tatap muka serta pengamatan tentang interaksi yang terjalin antar anggota grup tersebut. Penelitian offline dilakukan setelah penelitian online, artinya hal tersebut sebagai upaya untuk melakukan konfirmasi atau pengecekan terhadap fenomena yang diteliti. Selain itu, penulis juga melakukan penelitian online melalui pengamatan kepada anggota grup dalam WhatssApp "Monster Rabbit".

Para anggota kelompok tersebut adalah siswa SMP yang tersebar di wilayah kota \& kabupaten Bandung, yang menjadi subjek penelitian ini. Mereka adalah 13 orang remaja yang berusia 13 hingga 15 tahun. Mereka berasal dari berbagai sekolah menengah pertama di Soreang, Bandung yang menjadi anggota bahasa Inggris, yang kemudian menjadi salah satu identitas mereka.

Objek penelitian dalam penelitian ini adalah percakapan mereka di dalam grup WhatsApp yang ditautkan dengan kasus COVID-19. Teori konvergensi simbolik sangat relevan dalam penelitian ini, terutama untuk mengakui berbagai tema yang dikembangkan dan bagaimana tema rantai terbentuk dalam percakapan dalam menanggapi kasus COVID-19. Pengumpulan data yang dilakukan adalah wawancara mendalam melalui pertemuan tatap muka dengan informan, untuk memastikan temuan yang diperoleh penulis, setelah melakukan 
proses penelitian online. Selain itu, penulis juga melakukan teknik observasi dan juga studi dokumentasi. Pengamatan yang diterapkan adalah untuk melihat diskusi kursi di kelompok WhatsApp.

\section{HASIL DAN PEMBAHASAN}

Pendekatan virtual etnografi digunakan karena penelitian ini adalah tentang komunikasi yang terjadi dalam kelompok online. Ini membantu untuk mengakui budaya bicara yang muncul dalam kelompok ini dan juga tema diskusi yang muncul dalam kelompok.

Sebagaimana disebutkan sebelumnya, teori konvergensi simbolik adalah teori yang digunakan untuk mengungkap tema rantai dalam kelompok kecil. Subjek penelitian ini adalah kelompok remaja yang menyebut diri mereka "Monster Rabbit". Meskipun sesekali mereka mengubah status nama mereka sesuai dengan situasi. Pada saat ini, untuk kurun waktu yang lama, mereka memiliki grup nama identitas mereka dengan sebutan "Monster butuh Jalan jalan". Ketika diwawancarai, beberapa menyatakan bahwa mereka mengubahnya karena mereka benar-benar ingin keluar dan bermain bersama. Namun sayangnya, situasi COVID-19 tidak memungkinkan mereka untuk melakukannya. Hal tersebut tercermin pada gambar 1 yang merupakan profil gambar grup. Berikut ini adalah gambar lengkapnya.

Grup WhatsApp 'Monster Rabbit' atau 'Monster butuh jalan jalan' adalah sekelompok remaja berusia 13 dan 15 tahun. Penulis juga perlu mengungkapkan bahwa berdasarkan observasi online yang dilakukan, tercatat ada 11 anak perempuan dan dua anak laki-laki di dalam anggota. Mereka berasal dari sekolah yang berbeda di Soreang, tetapi mereka telah menjadi sekelompok teman, sejak mereka masih menduduki bangku Sekolah Dasar. Kemudian mereka mengikuti kursus bahasa Inggris yang membuat mereka lebih dekat satu sama lain, sehingga terbentuklah "Monster Rabbit".

Penelitian ini berfokus pada tema yang dikaitkan dengan COVID-19 di grup online mereka. Tema acara dimulai pada minggu kedua setelah pengumuman pertama penularan virus. Gambar 2 adalah jumlah kasus yang dikonfirmasi di seluruh dunia. Pada hari Sabtu 14 Maret 2020, otoritas kesehatan Indonesia di sisi lain mengkonfirmasi bahwa jumlah
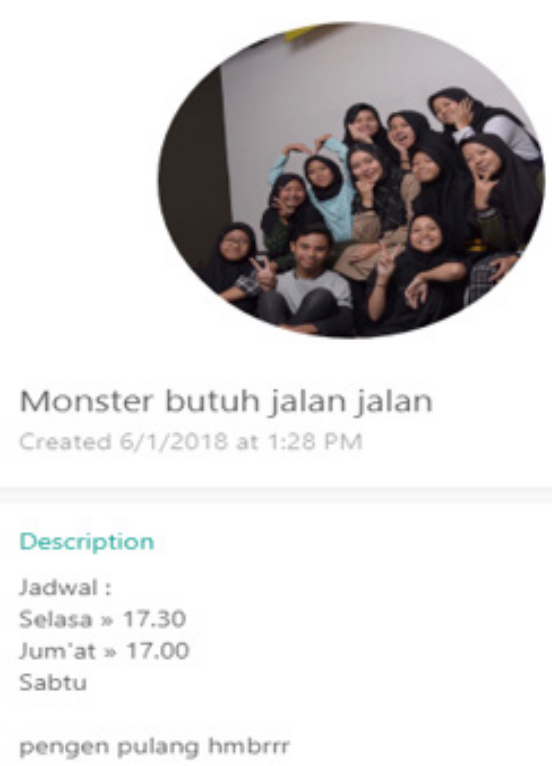

Sumber : WhatsApp Group, 2020

\section{Gambar 1 Profil Foto dalam Group WhatsApp Monster Rabbit}

kasus COVID-19 positif di negara ini telah meningkat menjadi 96, dengan jumlah kematian mencapai lima, dan juga di Indonesia (Cahya \& Pangestika, 2020).

Gambar 2 berhasil memancing diskusi yang terjadi pada kelompok "Monster Rabbit". Siapa yang menyangka jika ternyata kasus COVID-19 pun berdampak panjang hingga menyebar di dunia. Hal tersebut tidak hanya terjadi pada percakapan anggota kelompok "Monster Rabbit", ada studi yang sejalan membuktikan bahwa COVID-19 inipun menimbulkan terjadinya gejala kecemasan pada sebagian besar individu.

Hal tersebut dibuktikan dengan adanya sebuah hasil riset yang telah dilakukan oleh Huang \& Zhao sangat relevan dengan temuan penulis tentang mencuatnya tema ini sebagai topik percakapan yang tak kunjung habisnya bagi anggota kelompok "Monster Rabbit" (Huang \& Zhao, 2020). Menurutnya, studi berbasis web kami menunjukkan prevalensi tinggi GAD dan kualitas tidur yang buruk di populasi Cina selama epidemi COVID-19. Gejala kecemasan lebih mungkin terjadi pada orang berusia di bawah 35 tahun dan mereka yang menghabiskan terlalu banyak waktu memikirkan COVID-19. Dibandingkan dengan 


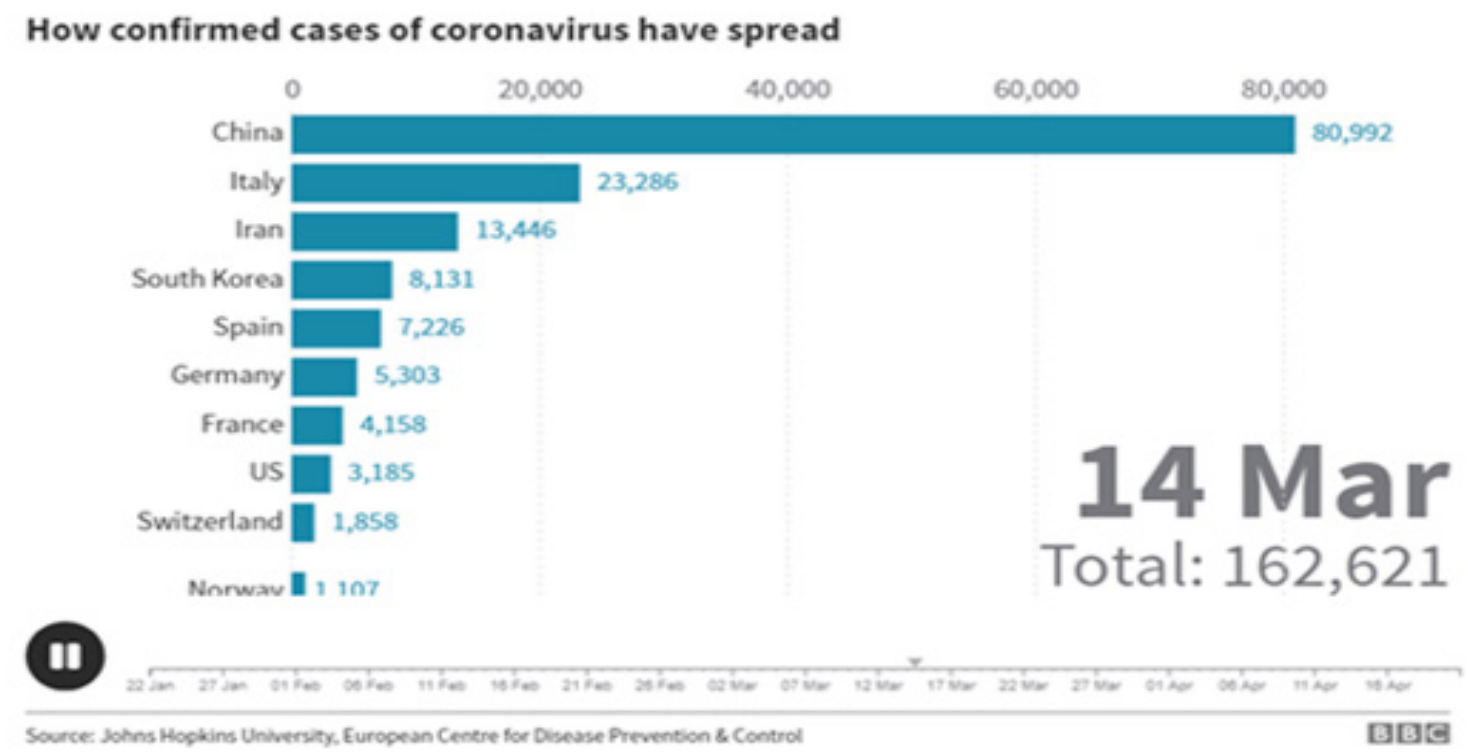

Sumber: Team, 2020

Gambar 2 Kasus COVID19 terkonfirmasi di dunia tertanggal 14 Maret 2020

profesi lain, petugas kesehatan dikaitkan dengan risiko lebih tinggi untuk kualitas tidur yang buruk. Temuan mereka memberikan dukungan data secara akurat dalam memahami sumber kepanikan publik selama epidemi COVID-19 (Huang \& Zhao, 2020).

Sebagai kesimpulan, mereka juga mengidentifikasi beban kesehatan mental utama masyarakat selama COVID-19 epidemi di Cina, dan orang muda, orang yang menghabiskan terlalu banyak waktu epidemi, dan petugas kesehatan beradapadarisikotinggimenampilkan psikologis masalah. Sebelumnya, ketika SARS terjadi di Tiongkok, kesadaran tentang publik kesehatan mental yang terkait dengan epidemi itu rendah, dan tidak ada pedoman psikologis yang ditargetkan tersedia untuk umum yang membutuhkan selama periode pandemi. Karena itu, berkelanjutan pengawasan dan pemantauan konsekuensi psikologis untuk wabah potensi epidemi, penyakit yang mengancam jiwa, membangun kesehatan mental target awal intervensi, harus menjadi rutin sebagai bagian dari upaya kesiapsiagaan di seluruh dunia (Huang \& Zhao, 2020).

Jika merujuk pada hasil penelitian Huang \& Zhao, penulis melihat adanya urgensitas dilakukan penelitian ini agar dapat mengungkapkan tentang tema percakapan yang terbentuk dari sebuah kelompok remaja
"Monster Rabbit", sehingga terlihat adanya gejala kecemasan yang tinggi serupa atau tidak dengan riset dari Huang \& Zhao tersebut (Huang \& Zhao, 2020). Berdasarkan hasil observasi online, penulis juga melihat bahwa kelompok remaja "Monster Rabbit" memulai percakapan mereka yang terkait dengan COVID-19 pada minggu kedua Maret 2020. Pada periode tersebut, kondisi yang terjadi di Bandung sendiri khususnya, belum ada pengumuman dari pemerintah bahwa sekolah dan universitas akan ditutup. Ini adalah seminggu sebelum pengumuman, dan pada saat itu, kondisi para remaja tidak siap belajar online dari sekolah. Ini adalah temuan yang menarik yang terjadi pada percakapan kelompok remaja yang membicarakan tentang COVID-19. Oleh karena itu, penulis memaparkan data hasil penelitian tersebut, dalam beberapa bagian di bawah ini, lebih tepatnya juga menggunakan teori konvergensi simbolik.

Grup WhatsApp ini pertama kali dibangun karena grup yang dibentuk dalam kehidupan nyata. Mereka adalah anggota kelas bahasa Inggris di salah satu kursus bahasa Inggris di Bandung. Para anggota, sebagaimana disebutkan di atas, adalah remaja berusia antara 13 hingga 15 tahun yang berasal dari berbagai sekolah menengah pertama.

Topik percakapan yang diskusikan lebih 
sering berkaitan tentang hal-hal yang berkaitan dengan kursus bahasa Inggris itu sendiri. Namun, karena mereka telah berada dalam satu kelompok selama lebih dari empat tahun, akhirnya mereka pun dapat berbicara tentang hal-hal lain, seperti gosip sekolah, topik yang sedang tren di media sosial, peristiwa yang sedang tren di media massa, dan bahkan percakapan yang terkait dengan kasus COVID-19. Apa yang mereka diskusikan terkait dengan COVID-19, sebagai sesuatu yang muncul di masa lalu dan berlanjut ke masa depan. Sehingga, akhirnya diskusi tersebut pun mengacu pada fantasi tema yang mencakup peristiwa dari anggota kelompok di masa lalu atau peristiwa di masa depan (Zanin, Hoelscher, \& Kramer, 2016).

Pada awal Maret 2020, ketika COVID-19 menjadi kasus yang memprihatinkan di seluruh dunia terutama di Indonesia. Para remaja ini datang dengan diskusi panjang yang terkait dengan COVID-19. Semuanya berawal dari apakah mereka sadar akan virus ini atau tidak. Gambar 3 adalah beberapa screen shoot pada percakapan mereka di grup whatsapp mereka. Seperti yang terlihat dari pengamatan online, mereka sadar bahwa COVID-19 adalah virus yang menyerang sistem pernapasan, yang sangat berbahaya bagi manusia. Beberapa tahu bahwa virus ini pertama kali ditemukan di
Wuhan, Cina. Salah satu anggota mengatakan bahwa itu dinamai corona karena tampaknya memiliki mahkota di atasnya.

Mereka juga mengetahui berapa lama virus akan tetap berada di tangan orang, sehingga orang harus selalu mencuci tangan . Mereka juga berbicara tentang gejalanya, yaitu; memiliki pilek, demam, dan batuk. Mereka juga sadar bahwa virus itu menular. Mereka khawatir karena mereka mengetahui bahwa obat anti-virus hingga saat percakapan tersebut berlangsung pun bahkan belum ditemukan.

Berdasarkan percakapan tersebut, maka penulis juga dapat mengaitkan adanya fokus utama tentang COVID-19 yang menjadi trending topic dalam berbagai media massa. Temuan penulis tentang percakapan berantai yang terjadi pada kelompok remaja tersebut, juga dibuktikan dengan adanya trending topic dalam media sosial twitter. Hal tersebut telah diungkapkan oleh Thelwall (Thelwall \& Levitt, 2020). Pandemi COVID-19 memiliki dampak yang sangat tidak merata pada sektor-sektor masyarakat. Orang-orang dengan disabilitas sangat rentan terhadapnya dan oleh karena itu penting untuk memahami perspektif disabilitas dan peran media sosial. Informasi ini dapat membantu mengurangi risiko penyakit. Sebagai tanggapan, artikel tersebut menggunakan

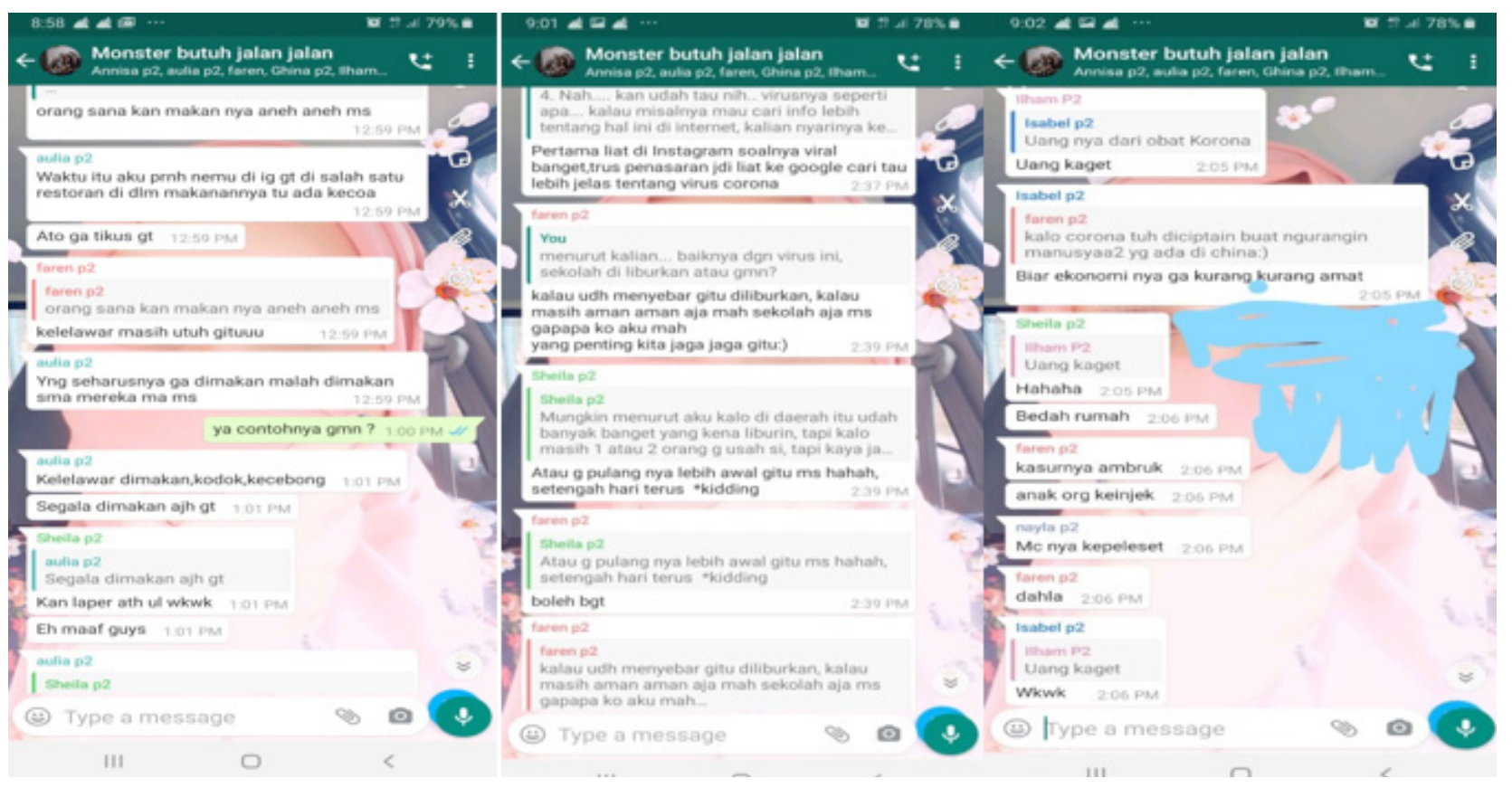

Sumber: WhatsApp Group, 2020

Gambar 3 Percakapan 'Monster butuh jalan jalan' 
analisis tematik untuk menyelidiki 59 tweet terkait disabilitas dari 10 Maret hingga 4 April 2020 yang di-retweet setidaknya 500 kali, dengan seperempat juta retweet sama sekali. Pendekatan ini menghasilkan wawasan cepat ke dalam isu-isu terkait disabilitas yang beresonansi secara luas. Hasilnya menyarankan bahwa Twitter sebagai media sosial yang mampu menyebarluaskan informasi tentang risiko, penawaran atau permintaan dukungan, kemampuan penyandang cacat untuk menyesuaikan diri dengan perubahan dengan baik, dan informasi tentang individu dengan penyakit tersebut. Seperti yang ditunjukkan oleh satu tweet, orang-orang dalam kategori yang kurang rentan tidak boleh diberikan informasi melalui Twitter atau di tempat lain, bahwa penyakit ini kurang relevan bagi mereka karena tindakan mereka dapat berdampak pada orang lain melalui penyebaran sosial (Thelwall \& Levitt, 2020).

Ahmed juga menguatkan tentang pandemik dari COVID-19 yang juga berdampak pada kondisi psikologis bagi individu yang menerima informasi tersebut (Ahmed et.all 2020). Menurut Ahmed virus RNA yang menyebar dari Wuhan, Cina. Hal tersebut berfokus pada dua negara, yaitu Cina dan Italia, telah mengunci penuh karena penyebaran cepat virus ini. Hingga saat ini, tidak ada data epidemiologis tentang masalah kesehatan mental karena wabah COVID-19 dan isolasi massal tidak tersedia. Untuk memenuhi kebutuhan ini, penelitian tersebut dilakukan untuk menilai status kesehatan mental orang Cina. Kurangnya kesempatan yang memadai untuk melakukan wawancara tatap muka, kecemasan, depresi, kesejahteraan mental dan perilaku konsumsi alkohol dinilai melalui langkah-langkah yang dilaporkan sendiri. Hasilnya menunjukkan tingkat kecemasan, depresi, penggunaan alkohol berbahaya dan berbahaya yang lebih tinggi, dan rasio kesejahteraan mental yang lebih rendah dari biasanya. Hasil tersebut juga mengungkapkan bahwa orang muda berusia 21-40 tahun berada dalam posisi yang lebih rentan dalam hal kondisi kesehatan mental dan penggunaan alkohol. Untuk mengatasi krisis kesehatan mental selama epidemi ini, sudah saatnya untuk menerapkan pendekatan multi-segi (yaitu membentuk tim kesehatan mental multidisiplin, menyediakan perawatan psikiatris dan layanan kesehatan mental lainnya, menggunakan platform konseling online, program rehabilitasi, memastikan perawatan tertentu bagi kelompok rentan dan yang lainnya (Ahmed et al., 2020).

Kedua rujukan penelitian tersebut dapat dilihat pada temuan penulis yang menggambarkan adanya rantai percakapan tentang COVID-19 yang diperbincangkan oleh kelompok remaja. Berbagai informasi tentang COVID-19 dibahas dalam grup media sosial yang digunakannya yaitu WhatsApp Group, informasi tersebut berkembang sampai mengangkat berbagai informasi yang diperolehnya dari sumber lain. Apalagi hasil penelitian Ahmed, et all (2020) mengungkapkan adanya kondisi psikologis yang terjadi karena COVID-19. Jika Ahmed, mengatakan bahwa kurangnya kesempatan yang memadai untuk melakukan wawancara tatap muka, kecemasan, depresi, kesejahteraan mental, dan perilaku konsumsi alkohol. Sementara itu, kondisi yang terjadi pada "Monster Rabbit" terdapat pada level mengurangi kecemasan tentang penyebaran informasi yang membanjiri platform media sosial yang mereka miliki.

Beberapa pesan yang mendramatisir, tetapi tidak semua, mengarahkan anggota kelompok lain untuk mengkomunikasikan pesan yang sama, suatu proses yang dikenal sebagai rantai fantasi (Zanin, Hoelscher, \& Kramer, 2016). Rantai fantasi, sebagaimana didefinisikan dalam grup ini, dimulai dengan beberapa percakapan tema yang terkait dengan kasus COVID-19. Permulaan tema dimulai dengan apakah mereka tahu atau tidak tentang kasus COVID-19, di mana mereka mendapatkan sebagian besar informasi, bagaimana perasaan mereka tentang hal itu dan apakah mereka tahu langkah-langkah untuk mencegah diri mereka sendiri dalam mendapatkan Virus. Bagian terakhir dari diskusi adalah tema yang mengungkap rantai fantasi yang memperdebatkan bagaimana Virus dapat muncul di tempat pertama dan menyebar ke seluruh dunia. Itu juga tentang apakah atau tidak pergi ke sekolah dalam situasi ini. Beberapa percakapan dapat dilihat pada Gambar 3.

Berdasarkan pengamatan online dan juga wawancara mendalam secara offline, remaja dalam grup obrolan anggota ini sepertinya menyimpulkan delapan alasan tentang bagaimana Virus ini menyebar ke seluruh dunia. Alasan-alasan ini tumbuh dari tema fantasi sebagai salah satu istilah kunci dari teori 
konvergensi simbolik.

Ada beberapa inti dari percakapan yang terjadi dalam kelompok remaja tersebut. Alasan pertama adalah bahwa COVID-19 ini muncul karena bagaimana 'orang Tionghoa', sebagaimana mereka menyebutnya, memiliki kebiasaan makan makanan aneh, aneh, kotor, dan terlarang. Mereka menyebutkan beberapa hewan seperti kelelawar, tikus, berudu, dan bahkan kecoak. Semua anggota kebanyakan percaya alasan ini. Pada awalnya, beberapa anggota meragukan alasan ini, tetapi ketika beberapa juga mengaku mendapatkan informasi ini dari media. Informasi ini membuat para anggota mempercayainya.

Alasan kedua adalah keyakinan bahwa ada sekelompok orang yang secara intensif membuat Virus untuk keuntungan. Beberapa anggota lain menyetujui pernyataan ini dan menyimpulkan bahwa alasan keuangan adalah tujuan utama. Beberapa yang lain juga setuju bahwa harus ada beberapa perjanjian bisnis rahasia di antara pihak-pihak rahasia. Salah satu mengatakan bahwa topeng, perusahaan sabun, akan mendapat banyak manfaat. Bahkan ada anggota yang mencoba meyakinkan temantemannya bahwa sudah ada obat anti-virus yang disimpan aman dan akan menjadi komoditas ketika orang mulai membutuhkannya.

Alasan ketiga adalah para anggota menyepakati bahwa COVID-19 merupakan hukuman dari Tuhan kepada sekelompok orang. Orang-orang ini, beberapa menyebut mereka sebagai 'orang Tionghoa' seperti dalam bahasa Inggris adalah 'orang Tionghoa', telah melakukan banyak dosa, itulah sebabnya Tuhan menghukum mereka. Semua anggota tampaknya memiliki pemikiran keagamaan tentang hal ini, berkaitan dengan latar belakang budaya mereka di mana mereka semua adalah Muslim. Mereka menyimpulkan bahwa orang- orang di Wuhan telah mengakui beberapa hal, dan Virus datang sebagai kutukan bagi mereka.

Alasan keempat adalah keyakinan bahwa bisa jadi militer Amerika yang dengan sengaja menyebarkan Virus ini karena beberapa percaya bahwa Cina dan Amerika Serikat sedang berperang. Secara khusus, satu mengatakan itu adalah perang dagang melawan keduanya. Simbol-simbol spesifik ini muncul sebagai hasil penelitian misalnya Ketika ada anggota grup yang langsung mengirimkan gambar militer Amerika, lalu direspon oleh anggota lainnya sehingga muncullah percakapan panjang membahas hal tersebut.

Alasan kelima mereka muncul adalah karena pemerintah China sendiri, yang secara sengaja menciptakan Virus ini untuk mengurangi populasi orang-orang Cina. Pada 2019, populasi Cina berjumlah sekitar 1,40 miliar orang. Prakiraan, sebagaimana dihitung oleh IMF, melihat populasi Cina tumbuh menjadi 1,41 miliar hingga 2022 (Textor, 2020).

Seperti terlihat pada gambar di atas, anggota kelompok ini menggunakan cara yang sangat santai dalam pidato mereka, meskipun mereka tampaknya menghargai satu sama lain dengan tidak menggunakan kata-kata kasar. Berikut ini adalah kategori budaya bicara yang mereka gunakan ditemukan dalam grup.

Bahasa sehari-hari. Bahasa yang digunakan dalam kelompok adalah apa yang orang sebut sebagai bahasa sehari-hari atau bahasa biasa, yang merupakan bahasa yang digunakan seharihari. Ini adalah bahasa yang tidak terstruktur, di mana penggunaan tata bahasa tidak signifikan. Bahasa seperti ini adalah gaya bicara yang paling umum.

Stiker WhatsApp. WhatsApp telah memfasilitasi penggunanya dengan stiker. Pengguna dapat dengan mudah menggunakannya untuk menekankan arti
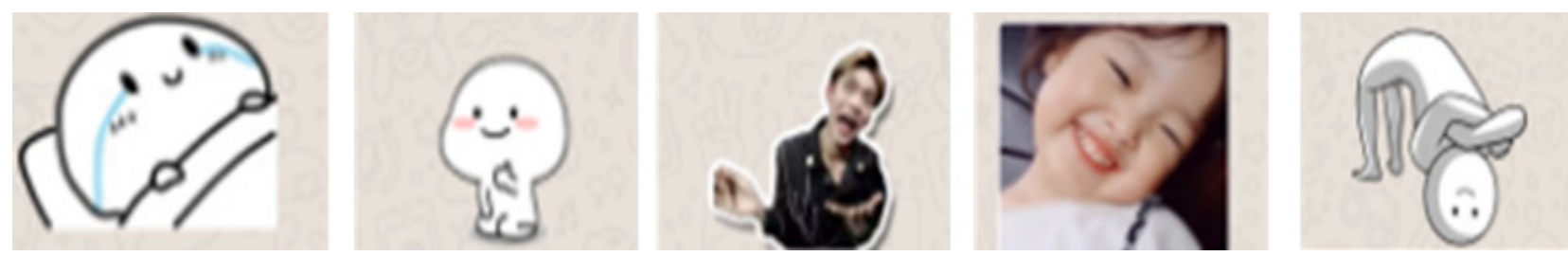

Sumber: Grup WhatsApp, 2020

\section{Gambar 4 Stiker yang digunakan dalam grup}


mereka dalam grup. Stiker juga digunakan untuk meredakan ketegangan yang perlahanlahan meningkat dalam kelompok karena ketidaksepakatan. Gambar 4 adalah beberapa stiker yang mereka gunakan selama rantai tema mereka membahas kasus COVID-19.

Gambar dari sumber lain. Gambar adalah tangkapan layar dari web untuk membuktikan argumen mereka yang ditautkan dengan kasus COVID-19. Rangkaian acara ini terjadi ketika mereka menyatakan keyakinan yang kemudian diperkuat dengan beberapa informasi yang mereka dapatkan dari berbagai situs web. Anggota dalam kelompok memutuskan pada sebuah pernyataan. Mereka membuktikan pernyataan mereka dengan juga memasukkan tangkapan layar. Gambar 5 adalah beberapa tangkapan layar yang mereka ambil.

Informasi yang mereka dapatkan dan bahas dalam grup berasal dari berbagai situs web, misalnya; kompas.com, www.who.int, youtube 'Doctor Mike'; 'Neuron', alodokter. com, halodoc.com, bbc.com, tribunnews.com, dan lain-lain.

Bahasa campuran. Budaya bicara dalam kelompok ini kadang-kadang menggunakan bahasa Indonesia dan Inggris dalam percakapan mereka. Ini adalah kebiasaan yang dihasilkan dari fakta bahwa mereka juga anggota kursus bahasa Inggris.

"Ya, saya tahu, Virus korona itu virus yang cukup berbahaya" (ya, saya tahu, virus korona bisa berbahaya), "Virus yang akan bertahan 10 menit di tangan" (Virus yang dapat bertahan di tangan Anda selama sepuluh) menit), "Aku merasa takut, takut kena". (Aku merasa takut, aku mungkin akan mendapatkannya). (Grup WhatsApp "Monster Rabbit")

Ini adalah beberapa rantai percakapan yang terjadi saat mereka membahas virus. Penggunaan bahasa campuran muncul sangat alami, sementara yang lain tidak keberatan. Berdasarkan Zanin (2016) pada lima elemen pentingpadavisiretorika dalamteorikonvergensi simbolik, pertama, persona dramatis adalah anggota grup WhatsApp 'Monster Rabbit' yang merupakan remaja yang berasal dari sekolah yang berbeda. kedua, plotline adalah tentang coronavirus yang pada awal Maret 2020 diumumkan sebagai pandemi. ketiga, adegan diskusi menguraikan rincian deskriptif tentang kesadaran virus, bagaimana mencegah pajanan dari virus, bagaimana mereka mendapatkan informasi dan asumsi mereka tentang mengapa virus itu menyebar dan dari mana asalnya.
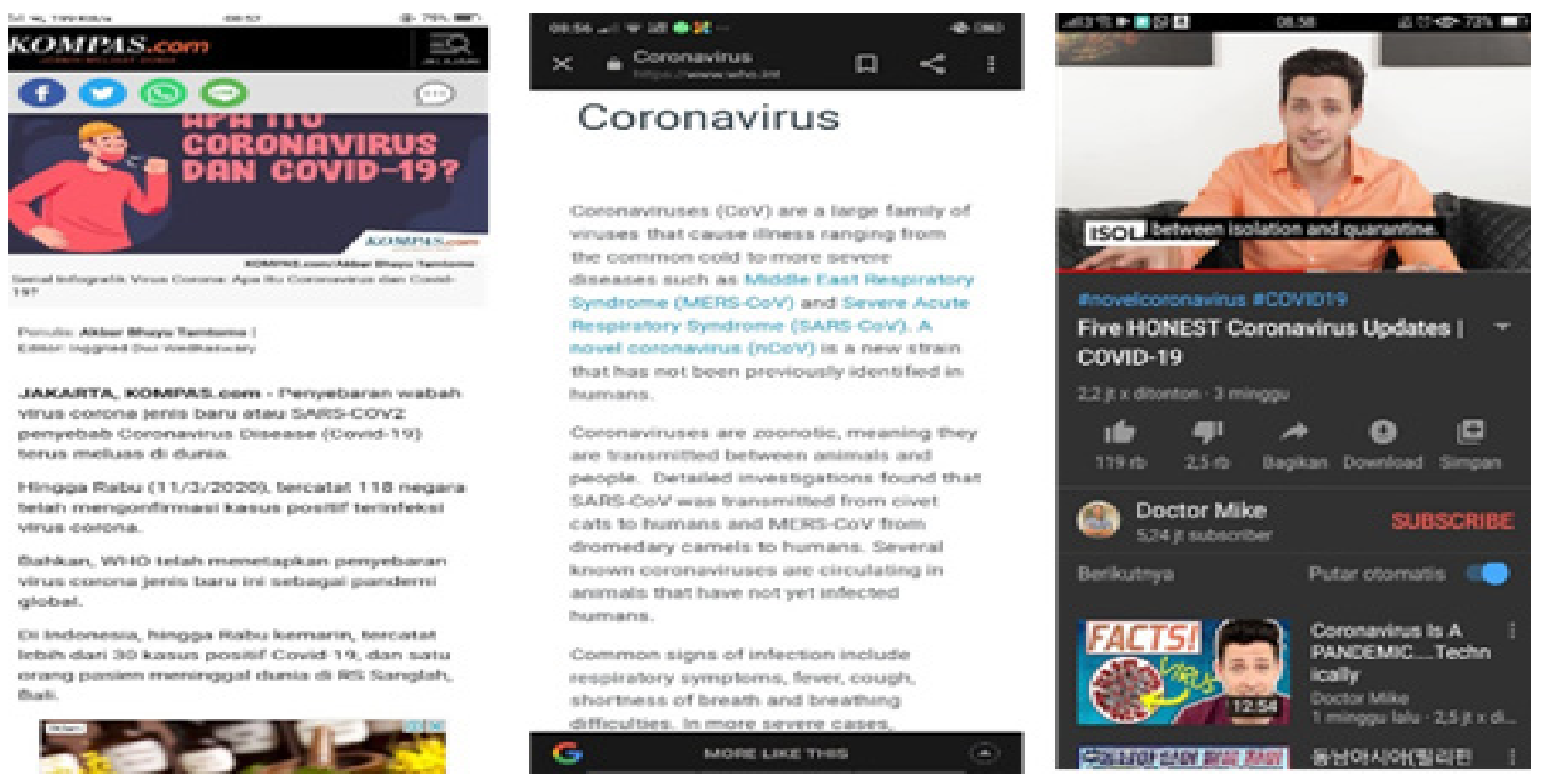

Sumber: Grup WhatsApp, 2020

Gambar 5: Tangkapan layar dari berbagai Informasi Virus 
keempat, agen sanksi adalah beberapa anggota yang sangat vokal, baik offline maupun online. kelima, master analog yang merupakan nilainilai tentang bagaimana virus bisa sangat menular dan berbahaya, dan orang-orang harus tahu bagaimana mencegah diri mereka sendiri dari virus ini. Ada juga keraguan dan pertanyaan panjang terkait dengan bagaimana virus ini dapat menyebar di tempat pertama dan apakah pihak-pihak tersembunyi sengaja membuatnya.

\section{SIMPULAN}

Pada akhir Februari 2020, Organisasi Kesehatan Dunia mengumumkan bahwa coronavirus (COVID-19) adalah pandemi, dan seluruh dunia harus mengambil tindakan untuk mencegah penyebaran. Grup WhatsApp 'Monster Rabbit' terpicu pada diskusi panjang tentang situasi ini. Berdasarkan teori konvergensi simbolik, tema yang muncul adalah tentang kesadaran mereka akan virus.

Tema rantai yang terbentuk dalam percakapan dimulai dengan apakah mereka tahu atau tidak tentang kasus COVID-19, di mana mereka mendapatkan sebagian besar informasi, bagaimana perasaan mereka tentang hal itu dan apakah mereka tahu langkahlangkah untuk mencegah diri mereka sendiri dalam mendapatkan virus. . Bagian terakhir dari diskusi adalah tema-tema yang mengungkap rantai fantasi yang memperdebatkan bagaimana virus dapat muncul di tempat pertama dan menyebar ke seluruh dunia. Itu juga tentang apakah atau tidak pergi ke sekolah dalam situasi ini.

Tema yang terkait dengan rantai pada debat tentang bagaimana virus dapat muncul pada awalnya cukup menarik. Itu mengurai empat alasan. Pertama adalah bahwa virus ini muncul karena bagaimana 'orang Cina memiliki kebiasaan makan makanan aneh, aneh, kotor dan terlarang. Alasan kedua adalah keyakinan bahwa ada sekelompok orang yang secara intensif menciptakan virus untuk keuntungan. Alasan ketiga adalah bahwa itu adalah hukuman dari Tuhan kepada sekelompok orang. Alasan keempat adalah keyakinan bahwa militer Amerikalah yang dengan sengaja menyebarkan virus ini. Alasan kelima adalah pemerintah China sendiri, yang dengan sengaja menciptakan virus ini untuk menunda populasi. Budaya bicara yang ditunjukkan dalam kelompok terdiri dari empat kategori, yaitu; penggunaan bahasa sehari-hari, penggunaan stiker yang difasilitasi oleh aplikasi, penggunaan screen shoot gambar dari situs web lain dan penggunaan bahasa campuran antara Indonesia dan Inggris.

Berdasarkan simpulan tersebut, penulis juga merekomendasikan agar topik penelitian peristiwa komunikasi yang membahas COVID-19 tetap dapat dilanjutkan dengan berbagai perspektif komunikasi yang menarik lainnya.

\section{DAFTAR PUSTAKA}

Ahmed, M. Z., Ahmed, O., Aibao, Z., Hanbin, S., Siyu, L., \& Ahmad, A. (2020). Epidemic of COVID-19 in China and associated Psychological Problems. Asian Journal of Psychiatry, 102092.

Cahya, G. H., \& Pangestika, D. (2020). COVID-19: Indonesia confirms fifth death, 96 positive cases -. National - The Jakarta Post. Retrieved April 27, 2020, from Thejakartapost.Com Website: Https://Www. Thejakartapost.Com/ News/2020/03/14/COVID-19-IndonesiaConfirms-Fifth-Death-96-Positive-Cases. Ht.

Chan, A. K. M., Nickson, C. P., Rudolph, J. W., \& Joynt, A. L. G. (2020). Social media for rapid knowledge dissemination: early experience from the COVID-19 pandemic. Pan American Health Organization WHO.

Diantina. P. (2020). Dana Rp72 miliar buat influencer, pemerintah gagap tangani COVID-19 - Tirto.ID. Retrieved April 21, 2020, from tirto.id website: https:// tirto.id/dana-rp72-miliar-buat-influencerpemerintah-gagap-tangani-COVID-19$e B r D$. Tirto.Id.

Ducharme, J. (2020). The who just declared coronavirus COVID-19 a pandemic| time. Retrieved April 22, 2020, from 2020 TIME USA website: https://time.com/5791661/ who-coronavirus-pandemic-declaration/. TIME USA Website.

Garfin, D. R., Silver, R. C., \& Holman, E. A. (2020). The novel coronavirus (COVID-2019) outbreak: amplification 
of public health consequences by media exposure. Health Psychology.

Gyimothy, S. (2013). Symbolic convergence and tourism social media. Tourism Social Science Series, 18, 55-71. Https://Doi.Org/10.1108/S15715043(2013)0000018006.

Heryanto, G. G. (2015). Konvergensi simbolik di media online: studi perbicangan netizens tentang polemik kasus century di era pemerintahan SBY-Boediono. Communication.

Hollander, J. E., \& Carr, B. G. (2020). Virtually perfect? telemedicine for COVID-19. New England Journal of Medicine.

Huang, Y., \& Zhao, N. (2020). Generalized anxiety disorder, depressive symptoms and sleep quality during COVID-19 epidemic in China: a web-based cross-sectional survey. medRxiv.

Jumiatmoko, M. (2016). Whatsapp messenger dalam tinjauan manfaat dan adab. Wahana Akademika: Jurnal Studi Islam Dan Sosial, 3(1), 51. Https://Doi.Org/10.21580/ Wa.V3i1.872.

Kobayashi et al., (2020). Communicating the risk of death from novel coronavirus disease (COVID-19). Journal of Clinical Medicine.

Kumar, D. (2020). Corona virus: a review of COVID-19. Eurasian Journal of Medicine and Oncology. Https://Doi.Org/10.14744/ Ejmo.2020.51418.

Littlejohn, S., Foss, K., \& Vaughan, D. R. (2012). Symbolic Convergence Theory.

Maxwell, J. A., \& Reybold, L. E. (2015). Qualitative research. in international encyclopedia of the social \& behavioral sciences: second edition (Pp. 685-689). Https://Doi.Org/10.1016/B978-0-08097086-8.10558-6.

Merchant, G. (2012). Unravelling the social network: theory and research. Learning, Media and Technology, 37(1), 4-19. Https://Doi.Org/10.1080/17439884.2011.5 67992.

Prasanti, D., \& Indriani, S. S. (2019). Analisis etnografi virtual tentang proses komunikasi kesehatan ibu dan anak dalam whatsapp group "tentang nak." Mediator: Jurnal Komunikasi. Retrieved March 26, 2020, from Mediator Website: Https://Ejournal.
Unisba.Ac.Id/Index.Php/Mediator/Article/ View/4654/Pdf.

Prasanti, D. \& I. (2018). Konvergensi simbolik tentang percakapan remaja laki-laki dalam media sosial group line. Jurnal Komunikasi Universitas Garut: Hasil Pemikiran Dan Penelitian, 4(1), 1-8. Https://Doi. Org/10.10358/JK.V4I1.352.

Rahmansari, R. (2018). Penggunaan aplikasi whatsapp dalam komunikasi organisasi pegawai dinas lingkungan hidup dan kebersihan Sidoarjo. Jurnal Ilmiah Manajemen Publik Dan Kebijakan Sosial, 1(2), 77-90. Https://Doi.Org/10.25139/ Jmnegara.V1i2.788.

Rheddy, S. (2020). Spreading facts, not fear, in the fight against Coronavirus | UNICEF Indonesia. Retrieved April 22, 2020, from Unicef.org website: https:// www.unicef.org/indonesia/stories/ UReportIndonesiaCoronavirus. UNICEF.

Sucio, P. (2020). COVID-19 misinformation remains difficult to stop on social media. Retrieved April 22, 2020, from Forbes website: https://www.forbes.com/sites/ petersuciu/2020/04/17/COVID-19misinformation-remains-difficult-to-stopon-social-media/\#396dc4384819. Forbes Website.

Suryadi, I. (2014). Teori konvergensi simbolik. In Academica, 2.

Team, T. V. and Journalism. D. (2020). Coronavirus pandemic: Tracking the global outbreak - BBC News. BBC News.

Textor, C. (2020). China: total population 1980-2024. Statista. Retrieved April 28, 2020, from Statista.Com Website: Https:// Www.Statista.Com/Statistics/263765/ Total-Population-of-China/.

Thelwall, M., \& Levitt, J. M. (2020). Retweeting Covid-19 disability issues: Risks, support and outrage. El Profesional de La Información (EPI), 29(2).

Trisnani. (2017). Pemanfaatan whatsapp sebagai media komunikasi dan kepuasan dalam penyampaian pesan dikalangan tokoh masyarakat. Jurnal Komunika: Jurnal Komunikasi, Media Dan Informatika, 6(3), 1-12. Https://Doi.Org/10.31504/ Komunika.V6i3.1227.

Van Bavel et al., (2020). Using social and behavioural science to support COVID-19 
pandemic response. Nature Human Behaviour, 1-12.

Zanin, A. C., Hoelscher, C. S., \& Kramer, M. W. (2016). Extending symbolic convergence theory. Small Group Research, 47(4), 438-472. Https://Doi. Org/10.1177/1046496416658554.
Wardani, A. S. (2020). 83 Persen pengguna internet indonesia pakai whatsapp -. Tekno Liputan6.Com. Retrieved April 24, 2020, from Liputan6.Com Website: Https://Www. Liputan6.Com/Tekno/Read/4113678/83Persen-Pengguna-Internet-IndonesiaPakai-Whatsapp\#. 